\title{
Differentiation of language functions during language acquisition based on Roman Jakobson's communication model
}

\author{
Lauri Linask \\ Department of Semiotics \\ University of Tartu \\ Jakobi 2, 51005 Tartu \\ Estonia \\ e-mail: lauri.linask@ut.ee
}

\begin{abstract}
The paper uses Roman Jakobson's conceptual framework to study the development of communication of children. It sets out to explain how cardinal functions of verbal messages - referential, emotive, conative, phatic, metalingual and poetic understood in terms of Jakobson's communication model - progressively differentiate during children's language acquisition. The differentiation of these functions is apparent in changes in children's use of language, as it corresponds to the gradual formation and adoption of various linguistic structures in the development of speech. Children's acquisition of the use of grammatical subject and predicate, corresponding to the appearance of specifically metalingual speech, among other linguistic structures, is related to children's adaptation to the linguistic environment. The article relates differentiation of metalingual and poetic functions to the development of children's thinking using the example of crib talk.
\end{abstract}

Keywords: Roman Jakobson; communication model; language functions; language acquisition; metalanguage; poetic function; crib talk; inner speech

\section{Introduction}

The paper advances the framework developed by Roman Jakobson (1896-1982) for studying the development of children's speech and communication in terms of differentiation of speech functions, and the corresponding changes that take place in the formation of linguistic structures during language acquisition. 
The list of possible uses that language may acquire is infinite, but languages themselves appear to be built in a highly ordered fashion. On the one hand, there are, for Jakobson, certain universal characteristics of all languages, e.g. their hierarchical build-up of levels of organization. On the other hand, there are basic common factors in each communicative situation of exchange of messages. Linguistics, then, as the study of the structure of messages and their underlying code, as well as language in all the variety of its functions (Jakobson 1971[1968]; 1985[1976]), must set out to study one in terms of the other, and vice versa. Indeed, it turns out that particular structures of messages, and the variety of linguistic structures more broadly, correspond well to the tasks that messages are set to fulfil in relation to the common basic factors of communicative situations (Jakobson 1981[1960]; 1985[1976]).

Because of the hierarchical build-up of language, the child's acquisition of language must take place in a systematic way. As the differentiation of functions is the differentiation of tasks that messages can fulfil in relation to basic constituents of a communicative situation, their development can be inferred from the appearance of different linguistic structures.

In "The grammatical buildup of child language" (Jakobson 1985[1977]), and, in even more detail, "The fundamental and specific characteristics of human language" (Jakobson 1985) Jakobson discusses the hierarchical buildup of language in terms of development of the main lingual structures in children's verbal development. In addition, Jakobson (1985) also hopes to compare those structures to communication in other species, as he understands it at the time of writing (the paper was originally presented in 1969). In these two papers, but also in many others, he suggested the necessity of relating the changes in functions of the communicative situation to the development of linguistic structures, or in other words, to changes in the makeup of children's messages. The present paper sets out to collect and organize these suggestions around the task Jakobson outlined. The outcome is a systematized view of both changes in individual language functions that take place during language acquisition and changes in interrelations between them, that adoption of particular structural characteristics brings along.

Jakobson based his communication model on verbal language, but also acknowledged its wider applicability to all communication systems. While some of his views on zoosemiotics (his general attitude towards the topic is summarized in Jakobson 1971[1967]) may appear outdated today, the article at hand also gives a brief overview of Jakobson's take on the functions of communication in other species. 


\section{Jakobson's communication model and language functions}

Roman Jakobson proposed his communication model in "Linguistics and poetics" (1960), although he had discussed it in its earlier stages of theoretical development even earlier (e.g. Jakobson 1981[1935]; 1971[1953]; 1971[1959]). Apparently, the earliest paper to cover the entire model, a conference presentation from 1956 entitled "Metalanguage as a linguistic problem" was published later (Jakobson 1976), while large parts of "Linguistics and poetics" repeat what was said there.

The communication model draws on earlier work by Karl Bühler in his Sprachtheorie (Bühler 2011 [1934]: 34-39), but it relates to Shannon's and Weaver's (1949: 7-8, 33-35) communication model as well. Jakobson also benefitted from other previous suggestions of individual language or speech functions, and functions of messages, mainly, among others, by Bühler, Sapir, Ogden and Richards, Marty, Malinowsky, Tarski, and the "Russian Formalists" and Mukařovský in their analyses of aesthetic and poetic devices as an object of study in linguistics.

Jakobson's communication model consists of an addresser and an addressee (sender and receiver or encoder and decoder in alternative terminologies used by Jakobson) of a message; the message itself; the context, whether verbal or potentially verbalizable, that the message refers to; a code wholly or partially common to both the sender and the receiver, "underlying the exchange of messages" (Jakobson 1971[1953]: 558) and connecting the signans and the signatum of the verbal sign; and a contact, "a physical channel and psychical connection" between the addresser and the addressee, enabling them to enter and maintain communication (Jakobson 1981[1960]: 21; 1985[1976]: 113). These elements constitute any act of verbal communication.

Those six constituent factors of the communication model determine the six functions or tasks that any message serves in a communicative situation - referential, emotive, conative, phatic, metalingual, and poetic, which are reviewed in more detail below. Jakobson's term 'function' derives from Tynyanov's writings in the late 1920s (cf. O'Toole and Shukman 1977: 32-33) and Jakobson and Tynyanov (1980[1928]), and can be described as follows: the function of each factor is its correlation with other factors and with the constructional principle of the whole. 


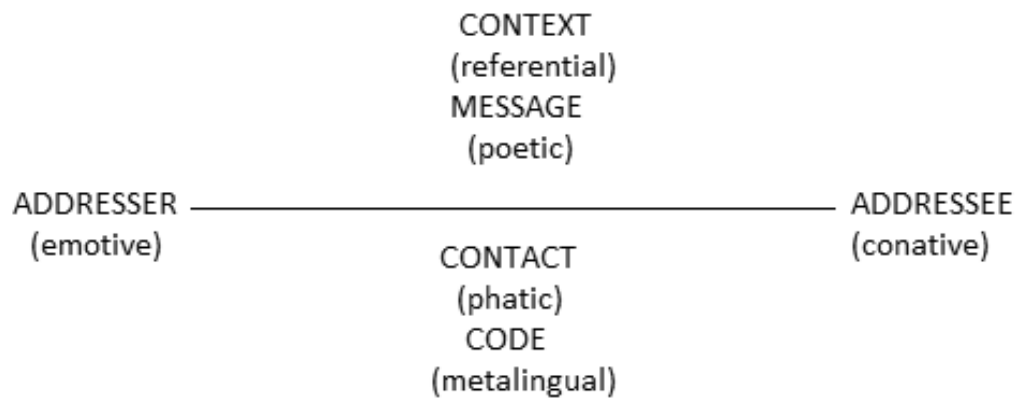

Figure 1. Jakobson's (1985[1976]) communication model and language functions.

Jakobson (1985[1976]: 113) explains that in communicative situations messages are seldom characterized by serving just one single function - they are a hierarchical bundle, a "set" or a "setting (Einstellung)" of functions. Rather than individual functions, it is interrelations between them that are important - how they are structured or work together in any particular setting. In settings, functions are either secondary subordinate or they have an organizing role as a constructional principle of the whole, in which case they are called the dominant or the determining function (cf. O’Toole and Shukman 1977: 34-35). The structure of any message reflects its particular hierarchical setting of functions. Certain linguistic structures are characteristic only of particular functions, and in languages, various phonological, morphological, lexical, and syntactical structures have formed to serve precisely these functions in messages.

It is worthwhile noticing, at this point, and from hereon, that the step-by-step buildup of the child's language is highly dependent on the hierarchical buildup of these levels. While the encoding of messages takes place "from meaning to sound and from lexicogrammatical to phonological level", decoding takes place in the opposite direction, "from sound to meaning, and from features to symbols" (Jakobson 1971[1961]: 575). In the beginning, infants only have access to sound, and the comprehension of meaningful units of a higher order must start from there. Acquisition of certain lingual structures is developmentally constrained by structures that must already have been learned, and this applies to all levels of organization. Likewise, appearance of certain functions is constrained by particular structures. This also explains why children (and adults) are much more competent as receivers than they are as senders. When receiving, the hierarchical makeup is determined; but when producing an utterance, the entire hierarchical makeup must be coordinated. 
While certain linguistic structures are characteristic only of particular functions, no function is restricted or limited to any particular linguistic structure, as functions rather arise from the communicative situation as a whole. Thus, messages can serve some functions by means of a variety of devices, even if particular structures have not been formed or are undifferentiated yet.

Despite that, functions do not exist independently of structures, but always manifest in them:

The structure of language underlies all of its manifestations, both patent and latent, and there can be no rupture between the structure and its purposes: an afunctional structure and a nonstructured function are both pointless and empty fictions. Our concepts are apprehended and delineated by the very fact of being named; this verbalizing activity endows them with permanence in time and continuity in space, and in this way secures and enhances our conservative ties with the past and creative connections with our future by securing and enforcing our future by securing and enforcing our intercourse with the environment. Our thought turns into an object of our naming and propositional activities, and our words and sentences in their interaction are converted into independent objects of our thought. (Jakobson, Waugh 1987[1979]: 82)

The differentiation of functions can be inferred by observing the use of specific structures.

The model applies mainly, but certainly not exclusively, to verbal messages, as Jakobson himself noticed. He also remarked that the possible presence and hierarchy of these basic functions should be studied in other semiotic systems as well, in terms of systems of signs broadly, not only in verbal signs as a specific type (Jakobson 1971[1967]; 1971[1968]). Despite that, his treatment of functions is highly language-centred and, as he drew the characteristics of functions on the basis of natural language, he saw other human communication systems only as derivative (e.g. Jakobson 1971[1953]; 1971[1967]). Jakobson developed these functions to relate particular structures of messages to the communication situation as a whole. Because of that, their application to communication systems out of the sphere of human communication must be handled with caution.

Below, the differentiation of language functions will be discussed in the order of their appearance in speech during children's language acquisition in terms of the emergence of particular linguistic structures. The six functions of language are compared and correlated to the step-by-step development of children's language acquisition and the emergent structures in the hierarchical buildup of children's language. This demonstrates how the differentiation of messages of particular function corresponds to the acquisition of linguistic structures by the child. 


\section{The differentiation of referential, emotive, conative, and phatic functions}

In a set focused or directed toward the context of the message, the dominant function is called 'referential' ('referential', 'denotative', 'cognitive' are terms used in Jakobson 1981[1960]; 1985[1976]; 'ideational' (Jakobson 1981[1960]); 'identifying', 'referential', 'cognitive', in Jakobson 1985; for 'representational' see Bühler 2011[1934]: 35, in other terminologies). While language is often conceived of in its 'referential' function, other functions must also be observed in any particular hierarchical setting even in cases of apparently referential messages.

The emotive or expressive function is focused on the addresser and "aims a direct expression of the speaker's attitude toward what he is speaking about" (Jakobson 1985[1976]: 114). It is an impression of an emotion or an attitude of the addresser, whether truthful or not. It is not the same as emotional speech, though, but a particular kind of linguistic coding of messages characterized by certain conventional structures (Jakobson 1981[1960]), hence, 'emotive', rather than 'emotional'. According to Jakobson, emotive messages are characterized by certain sound patterns often used distinctly for emotive purposes, and by their "syntactic role", as "they are not components but equivalents of sentences" (Jakobson 1985[1976]: 114).

While Jakobson did not agree with views holding that the emotive function is a non-linguistic feature of messages, as it sometimes derives from attitudes brought to messages from the outside, he did not think that the emotive function is restricted to verbal messages. Messages have an emotive function when they are coded to convey the speaker's attitude.

Messages oriented towards the addressee carry a conative ('appealing' in Bühler 2011[1934]: 35) function. The grammatically purest expression of conative function can be found in the vocative (as in turning to somebody, e.g. "I don't know, John", in which referential and conative functions are structurally related to each other) and the imperative. Imperatives differ from sets oriented towards the context in that they cannot be truth-tested.

Karl Bühler's (2011[1934]: 34-39) communication model is limited to these three functions.

The phatic function, a term introduced by Malinowsky (1946[1923]), is a setting directed at the contact of the communicative act to enter, sustain, and disconnect communication, as in specific forms such as "Hello!" or "Good-bye!" It can be used to catch attention and to check if the channel works, but it is also characteristic of ritualized formulas, purely for the sake of maintaining communication. 
The initial stage of the child's verbal development is the stage of single-word constructions, or in precise terminology, holophrases. Jakobson explains that early holophrases are functionally syncretic, "simultaneously emotive, conative, and referential" (Jakobson 1985: 93). However, not surprisingly, the first verbal function acquired by infants is the phatic function, as "they are prone to communicate before being able to send or receive informative communication" (Jakobson 1981[1960]: 24). As Jakobson described, these functions differentiate gradually from one another and, consequently, the purely referential subclass of holophrastic utterances emerges, "used chiefly or solely to designate and identify certain environmental items" (Jakobson 1985: 93).

Jakobson (1981[1960]: 24) claims that phatic communication, "typical of talking birds", is the only function birds share with human beings. In animal communication, messages which are specifically referential, free from the emotive or conative functions ("particularly from any role of exclamation, call, instruction, summon, order") have not been found, except between "certain tamed animals and their tamer", where "the former may be trained by the latter to respond to a limited number of outer stimuli in producing specific signals imparted by the trainer to his trainees" (Jakobson 1985: 93).

In the gradual multiplication of early holophrases, their differential components slowly become perceptible. The strict implicational laws determining the gradual differentiation of the phonemic system were described in Jakobson's book Child Language Aphasia and Phonological Universals (1968[1941]). Already at the holophrastic stage, the language of the small child has two distinct but interrelated systems of values: on the one hand, the system of meaning carriers and, on the other, the system based on "true contrast" (Jakobson 1985[1977]: 144), of "mere differentials of meaningful units" (Jakobson 1985: 94) - a duality of levels unique to humans.

The stage of single phrases follows the stage of holophrases. Phrases already consist of two components of which one, the modifier, is subordinated to the other, while the overall number of modifiers is, of course, very small at first. Jakobson (1985: 94) observed that this brings along higher complexity of grammar the difference emerges between the part (word) and the whole (phrase) of the utterance, the syntactical interdependence and the difference in the morphology of word-classes (of potential modifiers and those that cannot be modifiers) in its own respect giving rise to grammatical and lexical concepts. Jakobson also added that in species other than human, especially in birds, while there is accumulation of different signals, somewhat similar to strings of phrases in children's utterances, there is no "subordinative" interdependency in meaningful units of phrases, and thus no "intrinsic structural hierarchy" (Jakobson 1985: 94). 


\section{Development of metalingual function in subject-predicate clauses}

Messages have a predominantly metalingual function when they refer to the code of the message and its constituents. Jakobson dealt with the latter topic in "Metalanguage as a linguistic problem" (1985[1976]). Another similar paper, "Linguistics and poetics" (1981[1960]) rather focuses on devices in service of the poetic function in the context of other functions.

From Jakobson's point of view, the importance of metalanguage, a term developed by Alfred Tarski, lies both in one language describing another language, and in cases in which the "stock" of the object language is used to describe the language itself. Broadly speaking, it is talk about language and "meaning", but it does not concern only linguistics, semiotics or logic, but a large variety of everyday uses. For example, it includes checking whether the addresser and the addressee understand each other, whether they talk about or mean "the same thing", and all other ways of setting the frame of reference. The intimate connection between mastering a language and the development of metalanguage is what appears to have induced him "to propose a revision in the network of verbal functions" in the first place (Jakobson 1985[1980]c: 374).

For Jakobson, the appearance of metalingual function and talk about language is closely tied to the development of clauses with an explicit grammatical subject and an explicit grammatical predicate. In earlier stages, utterances remained as mere "verbal appendage to the immediate situation [...] an outward, hic et nunc observable and nonverbalized stimulus" (Jakobson 1985: 94). In subject-predicate clauses proper, "a mutual attachment of subject and predicate takes place in the clause itself" (Jakobson 1985: 94), not in the context of the utterance any more, providing the important step of liberating the referential speech from the attachment to the child's immediate perceptions. In other words, when "the same noun can be used with different verbs and the same verb is ascribed to different subjects" (Jakobson 1985[1977]: 146), clauses become free and variable from within the surrounding environment of the utterance.

Jakobson (1971[1962], 1971[1965], 1985[1972], 1985[1977]) strongly opposes views holding that the subject-predicate structure is "psychological", or somehow pre-linguistic. For him, the appearance and development of propositions is corollary to grammatical differentiation of the subject and the predicate of the clause. His views are well summarized in this example:

In English, there are three homonymous suffixes which have the sound $-z$, but which undergo fixed modifications $(-\partial z,-s)$ under certain phonetic conditions. 
This suffix form has three distinct meanings: first, that of the nominal plural (cooks); second, that of the possessive (cook's hat); and third, it is the inflectional form of the third person singular of the verb (mummy cooks). The child first utilizes this suffix for the plural ending, then for the possessive, and finally for the verb. $[\ldots / / \ldots]$ The reason is obvious: in differentiating between plural and singular, the word alone is involved, while in the use of the possessive form an entire phrase (cook's hat) comes into play. But when the person of the verb is involved, it is a question of the relationship between the predicate and the subject, and therefore the whole sentence is affected. (Jakobson 1985[1977]: 145-146)

In this example, the possessive is still attributive and its appearance comes with the previous stage, whereas for Jakobson, only the grammatical differentiation in the third case gives ground to a proper proposition. The development of propositions also entails truth testing and the appearance of "affirmation, negation and question [...] into the child's thought and language" (Jakobson 1985: 95).

Phrases of previous stages all had "a deictic ingredient" (Jakobson 1985: 95) merely pointing at the situation at hand, whereas subject-predicate clauses as propositions do not need to be related to any particular context at all. At this point, the linguistic structure starts providing means for the child to speak of "events distant in time and space or even fictitious" (Jakobson 1985[1972]: 90), and "the act of pointing" at the situation at hand is replaced by "pointing at the verbal context of one's own or interlocutor's message" (Jakobson 1985: 96). As verbal symbols gain independence from their particular contexts, they can be used both in their broad sense, as words as such and in general statements, and in their narrower, particular senses of application.

In essence, the child comes to realize the difference between words or sentences (the code) and particular utterances (the message). The development of clauses brings along the distinction of words and combination of words as coded units at a higher order of complexity, the sentence. Thus, for Jakobson (1985: 95), children also become aware of the freedom of choice of constituents into syntactic "matrices", thus giving ground to various kinds of verbal play. This will tie the metalingual to the poetic function, which is discussed subsequently.

The ability to refer to messages and codes gives rise to what Jakobson calls 'duplex structures': reported speech; proper names; shifters (e.g. personal pronouns and tenses, otherwise coded units, whose "general meaning implies a reference to the message", Jakobson 1985: 96); and most importantly for this discussion, explicitly metalinguistic speech, messages distinctly referring to the code.

Appearance of the metalingual function also entails appearance of equational propositions (including transfer of meaning, e.g. metaphor and metonymy) and statements of equivalence themselves, for example, in definitions. For Jakobson 
(1971[1959]; 1985[1972]), different types of translation - transformation, transference, translation and transposition - correspond to different kinds of relations of equivalence to the original; thus, translation essentially relies on the power of the metalingual function of language.

Moreover, giving meaning to a word in terms of other words of the same language makes it possible to discuss objects regardless of their ontological status: to use one of Jakobson's own examples, "centaurs are individuals combining the human head, arms, and trunk with the body and legs of a horse" (Jakobson 1985[1976]: 119). Thus, metalingual statements give birth to the discourse of objects that lack grounding within our experiential worlds, and discourses of fictitious objects. In setting up universes of discourse and frames of reference, the metalingual function also enables statements of existence and possible worlds, as in, "centaurs are mythical creatures" and "there are no centaurs in the real world".

For Jakobson, the development of metalanguage is vital to any kind of verbal development. In fact, in "On linguistic aspects of translation", in a debate with Bertrand Russell, Jakobson (1971[1959]) appears to hold the position that the "cognitive function" (in this case, in its power to generalize experience, and in contrast with early referential messages in holophrases and single phrases, which were deictic within their contexts) of language arises from linguistic meaning and its relations of equivalence with other "in some sense homogeneous signs of the same language" (Jakobson 1971 [1956]: 248) rather than from direct experiences. In that argument, but also in the case of the problem of explaining 'Chesterfield' to a unilingual Indian (Jakobson 1971[1953]), Jakobson clearly adopts the views advocated by Willard Van Orman Quine in his "Word and object" (1960).

In general, Jakobson (1985[1980]a) seems to align with the views of Mikołaj Kruszewski, Edward Sapir and Franz Boas that human consciousness has only little influence on linguistic processes and the development of language. This is simply to relieve attention and memory of the tremendous burden of dealing with the whole build-up of language at once, as speech is usually only a means to an end. However, the use of the metalingual function also enables bringing language itself into awareness, and thus makes conscious reflection on the code possible. Moreover, children appear surprisingly aware of the particular stage of their own language acquisition (Jakobson 1985[1980]a).

Jakobson relies on studies by Aleksandr Gvozdev and Kornej Chukovskij describing the significance and extent of use of metalanguage in pre-schoolers (Jakobson 1985[1976]; 1985[1977]; 1985[1980]a), who persistently reflect on language, deliberately correct and criticize the speech of others, compare verbal signs and: 
[...] are prone to compare new acquisitions with earlier ones and their own way of speaking with the diverse forms of speech used by the older and younger people surrounding them; the makeup and choice of words and sentences, their sound, shape and meaning, synonymy and homonymy are vividly discussed. A constant recourse to metalanguage is indispensable both for a creative assimilation of the mother tongue and for its final mastery. (Jakobson 1985[1976]: 120)

According to Jakobson (1985[1972]), metalanguage has no analogues in other sign systems. He says that neither spontaneous nor trained communication of species except human shows anything like clauses or other devices corollary with the appearance of clauses (Jakobson 1985). Thus, he maintains, there neither is an ability to propositionize, an ability to distinguish messages from the surrounding situations, nor to invent novel messages, as "the code is tantamount to the corpus of signals" (Jakobson 1985: 96). Consequently, there is neither hierarchical buildup, nor "general" and "particular", and none of the four "duplex structures". In fact, for him:

[...] [T] he chasm between the highest "zoosemiotic" patterns and even the earliest stages of transition from infancy to the gift of tongue is so deep that the cardinal dissimilarities widely outweigh the scanty correspondences. (Jakobson 1985: 97)

\section{The poetic function}

Jakobson (1985[1976]: 115) called the orientation toward the message itself, that is, with a "focus on the message for its own sake", the poetic function of language. Among the functions of language, the poetic function appears to have been closest to his heart, and his interest in it seems to have been the initial root of his interest in linguistic structures. As Jakobson (1985[1976]) insisted, not only is the poetic function characteristic of poetry or verbal art, but a constituent in all verbal activities. Neither is poetry functionally solely "poetic", but only in its dominant (Jakobson 1981[1935]; 1985[1976]).

The poetic function can be established already with devices on the level of phonemes (e.g. alliteration, assonance, the rhythm in syllabic patterns etc.). In fact, in "The sound shape of language", Jakobson and Waugh (1987[1979]: 217224) take a brief look at "children's verbal art" - the various ways in which the poetic function very often colours children's use of language in what is in the very beginning essentially play with sound and rhythm for its own sake. In fact, the poetic function has a well recognizable role in children's speech activities, which is discussed below in the example of crib talk. 
As infants only have access to signans, and not signatum, at the very beginning of their communicative activities they are definitely attracted to both sound and rhythm. Indeed, for Jakobson (1985[1980]b: 174), "in the confrontation of music with language the comparison must be confined solely to language in its poetic function". As the adoption of poetic function would mean the beginnings of children's artistic activities, we may ask if the differentiation of the poetic function finds its very beginnings already at the earliest stages of development. If the poetic function may become dominant already by means of devices from among phonemes, with "signatum of such an entity [...] bare otherness" (Jakobson 1971[1968]: 707), we may ask if speech with poetic function as one of its constituents might appear as early. But at least if the discussion is about verbal art, other structural aspects should be taken into account as well.

Thus, verse, for example, which is predominantly poetic, is not simply a recurrent "figure of sound" (Jakobson 1981[1960]: 38), but involves a semantic relationship between rhyming units. Thus, in verse, as Jakobson explained, the poetic function relies on specific interrelations between two basic modes of arrangement of verbal messages, selection and combination, or in other terms, the paradigmatic and the syntagmatic axes:

The selection is produced on the basis of equivalence, similarity or dissimilarity, synonymy and antonymy, while the combination, the build-up of the sentence, is based on contiguity. The poetic function projects the principle of equivalence from the axis of selection into the axis of combination. (Jakobson 1981[1960], emphasis in the original)

Either the code in metalingual function or the message in poetic function appears strange in its particular relations to other functions. An equivalence of some sort is what seems to be required in each case, which includes both paradigmatic and syntagmatic axes. If equivalence of some sort is required in the poetic function it means that the metalingual would have to be available for the child's creation of art, for the child to be able to recognize the message itself as distinct from the context of other stimuli of its situation. If both functions depend on equivalence, in what way are the two different? In fact, the two functions appear to be complete opposites functionally:

It may be objected that metalanguage also makes a sequential use of equivalent units when combining synonymic expressions into an equational sentence: $A=A$ ("Mare is the female of the horse"). Poetry and metalanguage, however, are in diametrical opposition to each other: in metalanguage the sequence is used to build an equation, whereas in poetry the equation is used to build a sequence. (Jakobson 1981[1960]: 27, emphasis in the original) 
Thus, the devices for setting up metalingual and poetic functions are also structurally distinct. The poetic function "deepen[s] the fundamental dichotomy of signs and objects" (Jakobson 1981[1960]: 25) by bringing signs themselves to the fore, whereas metalanguage appears to establish the relationships between parts of code, e.g. between signans and signatum. In "What is poetry?", Jakobson (1981[1933-1934)]) discusses the equivalency of sign and its object. In language, both awareness of the sign and the object's identity and of inadequacy of their identity are important, as "without contradiction there is no mobility of concepts, no mobility of signs, and the relationship between concept and sign becomes automatized. Activity comes to halt, and the awareness of reality dies out" (Jakobson 1981[1933-1934)]: 750).

\section{'Crib talk' at the intersection of emergent linguistic structures during the differentiation of language functions}

Jakobson (1971[1962]) discusses the relationship of metalingual and poetic functions, and inner speech in his introduction to Ruth Weir's famous book Language in the Crib (1962). In her book, Ruth Weir analyses observations of her son Anthony's speech behaviour in what is known as crib talk. As an example, crib talk seems to be well suited to explain the beginnings of the functional distinction of verbal art and the use of metalanguage from each other.

Crib talk is a speech phenomenon common to the second year of age, taking place as a small child's pre-sleep monologue ("a half-dream soliloquy" in Jakobson's terms - see Jakobson 1971[1962]: 285), when the child is already in bed, just about to fall asleep, distinctly when feeling that he or she is alone. In crib talk, certain features quite uncharacteristic of other uses of language in children of this age are observable, and it has a significant role in language acquisition.

Jakobson took crib talk to be a kind of early or preliminary stage of egocentric speech, a phenomenon previously observed and analysed by Lev Vygotsky who showed that in the development of the relationship between speech and thought, egocentric speech occurs as the intermediate stage between interpersonal speech, purely for social purposes, and inner speech, which is speech entirely for intrapersonal purposes (Vygotsky 1986[1934]: 29-36). Children are often observed talking to themselves aloud, vocally, especially when they are engaged in some activity on their own. This particular kind of speech often accompanies child's play, mostly when the child is alone, and it often occurs when the child is trying to solve a complex task, in which linguistic organization can be useful in providing structure to a potential solution. 
Vygotsky argued that, initially, speech activity is only overt, directed to other people, and only by going through a series of developmental steps does it become a means of organizing one's own thinking, acquiring an intramental role. The middle step in the interiorization of verbal signs, as Vygotsky and Luria (1994[1930]) called this developmental process, essentially entails the reorganization of thinking with the help of speech. Egocentric speech lies at the point of functional differentiation of inner speech from social speech. Egocentric speech, speech directed to oneself, is functionally closer to inner speech, but it is still vocalized, not silent. In brief, the purpose of egocentric and inner speech, in contrast to interpersonal speech, is to organize one's own behaviour. Because purely social speech and speech for oneself are useful for distinct purposes, they are not only distinguishable functionally, but also structurally.

Actually, in various papers, Jakobson (e.g. 1971[1953]; 1971[1967]; 1971[1968]; 1985[1972]; 1985[1974]; Jakobson, Waugh 1987[1979]: 81) argued that the intrapersonal aspect of communication is as important as the interpersonal one. He relies on both Vygotsky and Peirce when looking at inner speech as a dialogue between the self's past and future, as a transmission of meaning via signs from one state of mind to another. Understanding language as a communicative tool, interpersonal communication bridges space, whereas intrapersonal communication serves to bridge time (Jakobson 1985[1974]: 98). In fact, as "the phenomena of language belong to the phenomena of thought" (Jakobson 1985[1972]: 91), all speech has an internal aspect. It is also noteworthy that it seems that, both functionally and structurally, inner speech as distinctly intrapersonal speech cannot appear until speech can be liberated from its socially situated contexts, which, according to Jakobson, happens with the differentiation of the grammatical subject and predicate. Thus, inner speech with its structural characteristics, while distinct from the speech for others, maintains its fundamentally social nature:

Inner speech is radically elliptic; the sound shape of words receives a merely fragmentary evocation in our mind, and frequently they totally lose their phonic makeup ("zero signans"). However, neither these losses nor the tendency to replace verbal signs by other semiotic units permit us to return to an assumption of wordless, or even signless, asemiotic thinking. (Jakobson, Waugh 1987[1979]: 82)

Thus, because "[...] strictly speaking, what is acquired is a dialogue" (Jakobson 1985[1977]: 143), verbal thinking acquires its social character even when suited for individual tasks.

Both crib talk (usually observed between ages 1.5 and 2.5) and egocentric speech (common between ages 3 to 6 ) appear as speech purely for autocommunicative purposes. However, as Jakobson (1971[1962]) claims, while egocentric speech is 
directed to the addresser herself, it may thrive under certain conditions in the presence of others, whereas crib talk appears to be cut off when somebody comes around. As egocentric (like inner) speech has its own particular structure to suit its purposes, crib talk is also very distinct in its appearance. It is characterized by its particular elliptic but fragmented and condensed structure at the point of, sometimes at the intersection of, the formation of various hierarchical levels of language, thus providing a valuable source for studying language acquisition. Here, there is an excerpt from Ruth Weir's observation of little Anthony (28 to 30 months) talking to himself:

Step on the blanket - Where is Anthony's blanket - Where is Anthony's blanket (falsetto) - Where's hiding (falsetto) - Books - Down - Down - Have the books today - I take the white blanket off - On the blanket - Under the blanket - Sleep go - What a blue blanket - What the take the blanket... (Weir 1962: 126)

Crib talk often appears as grammatical and lexical exercises, with repetitions, alternations and alterations of fragmented words, phrases, clauses one after another; sentences taken apart into separate and autonomous components and built up again in a different way; alteration of modifiers for one head word and, conversely, alternating a selection of head words for one modifier; contrary and contradictory antonyms following each other; contrasting of different grammatical forms next to each other, but also contrasting of grammatical forms with purely phonemic forms and phonemic forms with each other.

Importantly for Jakobson (1971[1962]: 287), in crib talk, early predicate phrases are often practised - transitional forms between vocative-imperative sentences and subject-predicate sentences, which often come "without expressed subject or with a merely deictic pronominal subject (That's a kitty)" and are repeated for several times. For Jakobson, this provides more evidence for his view that subjectpredicate clauses are difficult to master, as the complexity in the idea takes the entire clause to another level of abstraction, and relates to his claim that children's language acquisition cannot start from the predicate, but must progress to get there, already discussed before.

These are just a few examples of signs of emergence and progressive differentiation of various syntactic and semantic structures in crib talk. Jakobson (1971[1962]: 287) analysed these and many other characteristic features of crib talk in his paper, concluding that "in the child's pre-sleep speech, lexical, morphological, and phonemic sets appear to be projected from the paradigmatic axis into the syntagmatic", remarkably a distinct feature of the poetic function described already before. This confirms that crib talk serves no other communicative purpose except trying out speech itself. 
Thus, from the point of language functions, in crib talk, "the lowering of the cognitive, referential function [...]", a noteworthy feature of all autocommunication, if not simply in its "mnemonic" function, "[...] brings to the fore all the other language functions" (Jakobson 1971[1962]: 286). Jakobson explains that while in an adult, the metalingual and the poetic functions appear quite different from each other, in children's speech there is "an intimate interlacement" (Jakobson 1971[1962]: 286) of the two functions and while the significance of the metalingual function was known, the "predominantly metalingual concern of the somnolent child with language itself comes as a great surprise" (Jakobson 1971[1962]: 286).

In summary, crib talk is a particular kind of autocommunicative speech in small children, which is used to practise and exercise language use. In crib talk, the metalingual function, as talk about language, is not yet differentiated among other speech functions, such as, notably, from the poetic function. The overall build-up of crib talk is set upon practising or playing with the linguistic construction itself, in contrast with communication with another person. It is a kind of a verbal play. While metalingual function of crib talk appears prominent, in crib talk, it "is not only an elaborate lesson in grammar but also [...] [a]nd above all, it is a true and beautiful poetic composition [...]" (Jakobson 1971[1968]: 288).

Both crib talk and egocentric speech appear as distinct stages of the same process, the gradual organization of speech with the help of distinctly autocommunicative messages. Interestingly, they are not so much of the type of autocommunication that Jakobson describes as being between the "self's past and future" (Jakobson 1971[1967]: 663), but of the type that was later fully analysed by Juri Lotman (1990: 20-35).

Both crib talk and egocentric speech often appear as play - as something that emerges within the performance of the activity, for the activity itself. In crib talk the focus is on the signans, trying out expressions, and its relations to its signatum, and in egocentric speech, the focus is rather on signatum, trying out content, regardless of its particular signans, e.g. whether spoken aloud or not. From this point of view, they both involve organisation of one's own activity by introducing secondary devices or means.

\section{Conclusion}

As language is mastered gradually, a "higher grammatical unity" (Jakobson 1985: 96) of complex sentences emerges, resulting in an even clearer discernment of addresser, addressee, referent, code, and message and, consequently, in a higher differentiation of verbal functions oriented towards each of them: 
The autonomy of these basic functions increases along with their higher integration. Their relative hierarchy exhibits a greater variability, and the alternation of distinct hierarchical patterns underlies the formation and diversification of verbal styles. (Jakobson 1985: 96)

Also, structural peculiarities of inner speech and its functional differentiation from external speech increase with age:

The active role of the metalingual function remains in force, undergoing considerable changes, to be sure, throughout our entire life and maintains the constant flux between the conscious and the unconscious in all our speech activity. (Jakobson 1985[1980]a: 160)

Metalingual messages acquire a special place during school years, when they come to be part of the development of formal thinking.

Conversely, the differentiation of functions may degenerate with the loss of use of certain linguistic structures. All through his academic life, Jakobson was very interested in various types of aphasia. It appears that while different types of aphasia correspond to different lines of progression of loss of language, overall, aphasia is recursive to language acquisition both structurally and functionally (Jakobson 1971[1956]; 1985[1980]b). For example, one of the types, the aphasic disturbances in the axis of selection - "the aphasic defect in the "capacity of naming" is properly a loss of metalanguage" (Jakobson 1971[1956]: 248).

In conclusion, the use of language changes during the entire life of a human being, and the hierarchical relations between functions, as they are set in the makeup of particular messages, change as well.

Jakobson's model of communicative situations corresponds to the structural buildup of messages that are used in these situations by the six functions that the messages have in relation to the six constituent factors of the model. Various linguistic structures enable the use of messages serving specific functions. Children are able to use messages for specific purposes if corresponding linguistic structures are available to them. The acquisition of the competence of using these structures is developmentally bound by the hierarchical buildup of language.

The six functions that messages may have in relation to constituent parts of the communication model are referential, emotive, conative, phatic, metalingual and poetic. While phatic communication appears earliest in the child's contact within a dialogue with another person, with the emergence of early holophrases and the beginning of linguistic coding, the use of messages appears. At this stage, children's messages are simultaneously referential, emotive and conative. The relationship between the functions begins to change with their subsequent differentiation from 
one another. In the use of phrases, the interrelations between functions become hierarchical, as a difference emerges between the part and the whole of the message, while part of the phrase becomes subordinate to the other part.

With the differentiation of the metalingual function from other functions, all other functions go through a radical change as well. For Jakobson, the metalingual function appears with the differentiation of the grammatical subject and predicate in messages (the appearance of clauses), which is "decisive for the whole of human organization" (Jakobson 1985[1977]: 147). With the emergence of subject-predicate clauses, messages are no longer situated in the immediate context of their uses. Grammatically, any subject may be assigned to any predicate, and children are happily willing to try out various combinations playfully. Emergence of clauses enables the free assignment of value to its constituents and liberates utterance from its contextual bounds. Importantly, it enables the distinction of the general meaning of the word from its particular contextual application. The freedom of propositions from their contextual bounds makes it possible to bring language and code in the focus of awareness.

Language acquisition depends on the child's ability to develop metalanguage (Jakobson 1985[1972]). Distinctly metalingual messages are used in communication to talk about the code and its constituent parts. Metalanguage is used for equational propositions, setting up frames of references, creating universes of discourse, including discourses of fictitious objects. Metalingual operations make it possible to explain terms in other terms, acquisition of new languages, and various other kinds of translation.

The differentiation of messages with distinctly aesthetic or poetic function is the beginning of children's art. Messages with a distinctly poetic dominant require the creative use of equivalences, and thus the poetic function appears to be similar to metalingual function, whereas, when properly differentiated in the course of development, the structural principle of their construction is opposite. An intricate relationship between the metalingual and poetic functions is observable in the phenomenon known as crib talk.

From the point of view of language acquisition, crib talk is predominantly metalingual, but by its structural composition and its play-like character, it appears to belong in the sphere of poetry. 


\section{References}

Bühler, Karl 2011[1934]. Theory of Language: The Representational Function of Language. Amsterdam: John Benjamins Publishing Company.

Jakobson, Roman 1968[1941]. Child Language Aphasia and Phonological Universals. The Hague: Mouton Publishers.

- 1971[1953]. Results of a joint conference of anthropologists and linguists. Selected Writings II. Word and Language. The Hague: Mouton, 555-567.

- 1971[1956]. Two aspects of language and two types of aphasic disturbances. Selected Writings II. Word and Language. The Hague: Mouton, 239-259.

- 1971[1959]. On linguistic aspects of translation. Selected Writings II. Word and Language. The Hague: Mouton, 260-266.

- 1971[1961]. Linguistics and communication theory. Selected Writings II. Word and Language. The Hague: Mouton, 570-579. [Originally presented in 1960]

- 1971[1962]. Anthony's contribution to linguistic theory. Selected Writings II. Word and Language. The Hague: Mouton, 285-288.

- 1971[1965]). Quest for the essence of language. Selected Writings II. Word and Language. The Hague: Mouton, 345-359.

- 1971[1967]. Linguistics in relation to other sciences. Selected Writings II. Word and Language. The Hague: Mouton, 655-696.

- 1971[1968]. Language in relation to other communication systems. Selected Writings II. Word and Language. The Hague: Mouton, 697-708.

- 1981[1933-1934]. What is poetry? Selected Writings III. Poetry of Grammar and Grammar of Poetry. The Hague: Mouton Publishers, 740-750.

- 1981[1935]. The dominant. Selected Writings III. Poetry of Grammar and Grammar of Poetry. The Hague: Mouton Publishers, 751-756.

- 1981[1960]. Linguistics and poetics. Selected Writings III. Poetry of Grammar and Grammar of Poetry. The Hague: Mouton Publishers, 18-51. [Originally presented in 1958]

- 1985. The fundamental and specific characteristics of human language. Selected Writings VII. Contributions to Comparative Mythology. Studies in Linguistics and Philology, 1972-1982. The Hague: Mouton Publishers, 93-97. [Originally presented in 1969]

- 1985[1972]. Verbal communication. Selected Writings VII. Contributions to Comparative Mythology. Studies in Linguistics and Philology, 1972-1982. The Hague: Mouton Publishers, 81-92.

- 1985[1974]. Communication and society. Selected Writings VII. Contributions to Comparative Mythology. Studies in Linguistics and Philology, 1972-1982. The Hague: Mouton Publishers, 98-100.

- 1985[1976]. Metalanguage as a linguistic problem. Selected Writings VII. Contributions to Comparative Mythology. Studies in Linguistics and Philology, 1972-1982. The Hague: Mouton Publishers, 113-121. [Originally presented in 1956]

- 1985[1977]. The grammatical buildup of child language. Selected Writings VII. Contributions to Comparative Mythology. Studies in Linguistics and Philology, 1972-1982. The Hague: Mouton Publishers, 141-147. [Originally presented in 1975]

- 1985[1980]a. On the linguistic approach to the problem of consciousness and the unconscious. Selected Writings VII. Contributions to Comparative Mythology. Studies in 
Linguistics and Philology, 1972-1982. The Hague: Mouton Publishers, 148-162. [Originally presented in 1978]

- 1985[1980]b. Brain and language: Cerebral hemispheres and linguistic structure in mutual light. Selected Writings VII. Contributions to Comparative Mythology. Studies in Linguistics and Philology, 1972-1982. The Hague: Mouton Publishers, 163-180.

- 1985[1980]c. My favorite topics. Selected Writings VII. Contributions to Comparative Mythology. Studies in Linguistics and Philology, 1972-1982. The Hague: Mouton Publishers, 371-376.

Jakobson, Roman; Tynjanov, Juri 1980[1928]. Problems in the study of language and literature. Poetics Today 2(1a): 29-31.

Jakobson, Roman; Waugh, Linda 1987[1979]. The sound shape of language. Selected Writings VIII. Completion Vol. 1. Berlin: Mouton de Gruyter, XVIII-314.

Lotman, Yuri M. 1990. Universe of the Mind: A Semiotic Theory of Culture. (Shukman, Ann, trans.; Eco, Umberto, intr.) Bloomington, Indianapolis: Indiana University Press.

Malinowski, Bronislaw 1946[1923]. The problem of meaning in primitive languages. In: Ogden, Charles Kay; Richards, Ivor Armstrong, The Meaning of Meaning: A Study of the Influence of Language upon Thought and of the Science of Symbolism. New York: Harcourt, Brace \& World, 296-336.

O’Toole, Lawrence Michael; Shukman, Ann (eds., trans.) 1977. A contextual glossary of formalist terminology. In: O’Toole, Lawrence Michael; Shukman, Ann (eds.) Formalist Theory. Russian Poetics in Translation. Vol. 4. Oxford: Holdan Books, 13-48.

Quine, Willard Van Orman 1960. Word and Object. Cambridge: MIT Press.

Shannon, Claude Ellwood; Weaver, Warren 1949. The Mathematical Theory of Communication. Urbana: University of Illinois Press.

Vygotsky, Lev 1986[1934]. Thought and Language. Cambridge: MIT Press.

Vygotsky, Lev; Luria, Alexander 1994[1930 - unpublished original]. Tool and symbol in child development. (Prout, Theresa, trans.). In: Van der Veer, René; Valsiner, Jaan (eds.), The Vygotsky Reader. Oxford, Cambridge: Blackwell, 99-174.

Weir, Ruth Hirsch 1962. Language in the Crib. The Hague: Mouton.

\section{Дифференциация языковых функций в процессе овладения детьми языком на основе коммуникационной модели Романа Якобсона}

В статье используется модель Романа Якобсона для изучения развития коммуникации у детей. Цель статьи - объяснить, как выделенные Якобсоном функции словесных сообщений - референтивная, эмотивная, конативная, фатическая, метаязыковая и поэтическая - последовательно дифференцируются во время детского овладения языком. Различение этих функций становится очевидным в ходе исследования детского использовании языка, поскольку соответствует постепенному формированию и оосвоению различных лингвистических структур в ходе развития речи. Появление грамматического субъекта и предиката в предложении соответствует появлению метаязыковой функции среди других лингвистических структур и связано с детской адаптацией к окружающей языковой среде. Дифференцирование метаязыковых и поэтических функций в развитии детской речи хорошо просматривается при изучении детского лепета (crib talk). 


\section{Keelefunktsioonide eristumine laste keeleomandamise käigus Roman Jakobsoni kommunikatsioonimudeli põhjal}

Artikkel võtab laste kommunikatsiooni arengu uurimiseks kasutusele Roman Jakobsoni mõistestiku. Püütakse selgitada, kuidas verbaalsete teadete funktsioonid - referentsiaalne, emotiivne, konatiivne, faatiline, metakeeleline ja poeetiline - mida mõistetakse Jakobsoni kommunikatsioonimudeli raamistikus, laste keeleomandamise käigus üksteisest progresseeruvalt eristuvad. Keelefunktsioonide eristumine muutub ilmseks laste keelekasutuse uurimise käigus, sest vastab erinevate keele struktuuride moodustumisele ja nende kasutamise järkjärgulisele omandamisele kõne arengu käigus. Grammatilise subjekti ja objekti eristumine lausete moodustamisel vastab laste keeleomandamise käigus metakeeleliste teadete moodustamise ilmumisele - teiste uute keelestruktuuride seas - ning on seotud laste kohandumisega oma keelekeskkonnaga. Metakeelelise ja poeetilise funktsiooni eristumine on laste keele ja mõtlemise suhete arengus vaadeldav hällikõnes. 